\title{
The dividend puzzle: testing the signalling hypothesis in a European context
}

\section{Júlio Lobão*}

School of Economics and Management,

University of Porto,

Porto, Portugal

Email: jlobao@fep.up.pt

*Corresponding author

\section{Luís Pacheco}

Department of Economics and Management,

and

REMIT - Research on Economics, Management and

Information Technologies,

Portucalense University,

Porto, Portugal

Email: luisp@upt.pt

\section{Tiago Lajas}

School of Economics and Management,

University of Porto,

Porto, Portugal

Email:200504735@fep.up.pt

\begin{abstract}
Dividend policy continues to puzzle researchers in the discipline of finance. In this paper we test the signalling effects of the dividend payout for a set of European firms that had sustained earnings growth for a minimum period of five years with a decline in the last year. To the best of our knowledge this is the first paper to run and compare the results of several different models including the recently created simultaneous-equation model in its linear and nonlinear forms alongside a simple OLS-based estimation. Our results show that managers change dividends to signal equity-scaled earnings prospects instead of asset-scaled earnings. We also find evidence that managers change dividends for signalling previous earnings changes and may distribute dividends to reduce agency costs. These findings suggest that managers identify shareholders as the accepters of dividends and the most direct targets to signalling information.
\end{abstract}

Keywords: dividends; signalling hypothesis; behavioural finance; European firms; simultaneous-equation model.

Reference to this paper should be made as follows: Lobão, J., Pacheco, L. and Lajas, T. (2020) 'The dividend puzzle: testing the signalling hypothesis in a European context', Int. J. Banking, Accounting and Finance, Vol. 11, No. 2, pp.202-226. 
Biographical notes: Júlio Lobão is a Professor of Finance in the School of Economics and Management at the University of Porto in Portugal. He teaches courses primarily in financial markets. He received his $\mathrm{PhD}$ in Managerial Studies from the University of Minho (Portugal). His research focuses on behavioural finance and financial markets.

Luís Pacheco teaches at Universidade Portucalense, in Porto - Portugal. He holds a PhD in Economics from the Technical University of Lisbon, an MSc in Monetary and Financial Economics and a degree in Economics. He teaches at undergraduate and master degrees in the financial and economical area, doing is research in the fields of finance and tourism areas.

Tiago Lajas is an Assistant Manager at A. Saraiva and Saraiva, Lda, in Vila Nova de Gaia - Portugal. He holds an MSc in Finance from the School of Economics and Management at the University of Porto, a degree in Management and a Degree in Economics from the Universidade Portucalense Infante D. Henrique (Portugal).

\section{Introduction}

The dividend policy has been one of the most important themes of study in finance since the 1950s. Despite this, the dividend decision continues as one of the most controversial topics in financial economics.

One specific area of research focused in this paper is the theory of dividend signalling which states that dividends provide signals to the market in terms of the future prospects of a firm. Most recent studies on this topic have used US data (e.g., DeAngelo et al., 1996; Grullon et al., 2005) and UK data (e.g., Ap Gwilym et al., 2004; Hussainey and Aal-Eisa, 2009; Bozos et al., 2011). The majority of the studies obtained mixed results however the most recent ones seem to point to the irrelevance of the signalling capacity of dividends.

Scholars supporting the theory of dividend signalling argue that dividends help to mitigate agency problems between managers and investors who are less informed about the firm's prospects. Those against the theory point out that dividends contain no signal to investors and that even if there was some kind of signal it would be an erroneous one since managers suffer from several behavioural biases (e.g., over optimism).

In this paper we analyse the dividend policy of a set of European firms that had sustained earnings growth for a period of at least five years with a decline in the last year. We test the empirical importance of dividend signalling by using a different sample from previous authors who either focused on a single market (e.g., US, UK) or used a much smaller sample size or data period. In this paper we recur to a battery of different models in order to test the robustness of our results. Among other models, we use the simultaneous-equation model system developed by Liu and Chen (2015) that regress current dividend changes on future earnings changes and at the same time control for additional motives of dividend changes as well. This model is especially useful as it addresses the mutually endogenous problem between dividend changes and future earnings changes that are not usually fully controlled with other methods. Furthermore, it is also employed the simultaneous-equation model both in its linear and nonlinear forms as developed by Nissim and Ziv (2001) and Grullon et al. (2005), respectively. 
This paper is organised in as follows. Section 2 briefly reviews the literature regarding the dividend policy. Section 3 presents the data and methodologies used in this paper. Section 4 presents the empirical results. In Section 5 we conduct a series of robustness tests. Section 5 concludes the paper.

\section{Literature review}

\subsection{Dividend policy theories}

It is plausible to assume that the dividend policy is influenced by a number of factors. Among these factors we may include the firm's current net earnings, future Capex needs and stream of cash flows, the investors' preferences or even the market sentiment. We can also add competitors to these factors as managers usually look at what is being done by others when setting the policy. Other factors are related to human nature like the managerial profile, behavioural biases and reasons that may lead the manager to send false information.

The dividend policy depends on how much of the net earnings are available to be used as dividends and the future investment opportunities since these will require additional cash flows that can be financed using the firm's current earnings instead of using the costly alternative of external financing. High-growth firms will not pay large dividends because they need net earnings to support their growth and the largest and more profitable firms are the ones that usually pay the highest dividends and are more likely to increase those (Grullon et al., 2005).

Finally, past studies (e.g., DeAngelo and DeAngelo, 1990) have concluded that firms have a preference for stable dividends. Some authors argue that this happens because dividend policy is a kind of ritual between managers and shareholders and solves some of the agency problems that can be created with the opposition of interests between managers and investors (Frankfurter and Lane, 1992).

It is possible to find in the literature several theories concerning the distribution of dividends namely: the dividend irrelevance theory (Miller and Modigliani, 1961; Lumby and Jones, 1981); the agency theory (Jensen and Meckling, 1976); the information asymmetry theory (Bhattacharya, 1979; John and Williams, 1985; Miller and Rock, 1985); the bird-in-hand fallacy (Bhattacharya, 1979; Damodaran, 2006); the clientele effect (Lumby and Jones, 1981, Allen et al., 2000); and finally, the most relevant to this paper, the dividend signalling theory.

\subsection{The signalling hypothesis}

The dividend signalling hypothesis implies that dividends contain information that can be used to signal the market about a firm's future prospects, namely its earnings. This theory about the 'information content of dividends' was first presented by Miller and Modigliani (1961).

There are two distinct views about this theory: one according to which dividends contain signals about future earnings and another in which changes in the dividend policy contain no such insight on future prospects. Among the first group of scholars, Lintner (1956) showed that changes in earnings impact the dividend policy. Fama and Babiak (1968) achieved similar results, attesting that dividend changes contained lagged changes 
in earnings. On the opposite side, it was argued that firms do not want to decrease dividends because such a movement is negatively viewed by the market and tends to cause a decrease in share prices (Eades, 1982; Damodaran, 2006).

Over the decades, two different hypotheses related to the Dividend Signalling Theory have come up: the free cash flow hypothesis and the maturity hypothesis. The free cash flow hypothesis states that the dividend policy of a firm reflects information on the investment policies of overinvestment firms (Litzenberger and Ramaswamy, 1979). So, if a firm increases its dividends it could mean that they lack investment opportunities and are just trying to attract new investors. The maturity hypothesis states that an increase in dividends means not only less investment opportunities but as well less returns on assets, less future earnings prospects and less systematic risks (Grullon et al., 2002; Charitou et al., 2011).

A number of past studies found evidence that managers use changes in dividends as a way to signal information about future earnings of a firm. Bhattacharya (1979), John and Williams (1985), Miller and Rock (1985), Kao and Wu (1994), Fama and French (1998) and more recently Harada and Nguyen (2005) and Baker et al. (2006) suggest that changes in dividends are a tool that managers frequently use to convey data about unexpected shocks in earnings.

Earlier studies (Brickley, 1983; Healy and Palepu, 1988) found that an increase in dividends tends to lead to the increase in future earnings. These findings propelled further research in the topic of the signalling hypothesis, with Aharony and Dotan (1994) finding that firms that decrease dividends experience less unexpected changes in earnings in the following years. Finally, Nissim and Ziv (2001) also found evidence of a positive relationship between current dividend increases and changes in earnings in the subsequent two years while controlling a linear form of mean reversion in earnings.

Marsh and Merton (1987) initially defended the signalling hypothesis but later considered it unlikely when finding evidence that managers react to the dividend announcements of their competitors and as such will always be conditioned when setting their own dividend policy. Benartzi et al. (1997) argued against the existence of a relationship between changes in dividends and changes in earnings in subsequent years. In fact, their research discovered a new phenomenon: the earnings reversal phenomenon which is identified when changes in dividends reflect changes in earnings in the current year.

Fudenberg and Tirole (1995) identified a trend amongst managers which in turn makes dividends sticky. Accordingly, managers are unwilling to decrease dividends as they fear negative response by the shareholders and the market. They only decrease dividends as a last resort and if they are sure the earnings will not grow in the following years.

Finally, a recent study from DeAngelo et al. (2009) identified the influence of behavioural bias at the managerial level like overconfidence and the idiosyncratic preferences of controlling stockholders as having a major impact on the dividend policy.

\subsection{Similar studies}

The majority of empirical studies on the signalling capacity of dividends were focused on the North American market with only a few studying European markets, mainly the UK. 
Using an earnings growth model, DeAngelo et al. (1996) found no support for the notion that dividend decisions help identify firms with superior future earnings, arguing that dividends tend to send unreliable signals because of: behavioural bias (over optimism) that leads managers to overestimate future earnings; modest cash commitments when managers do increase dividends; and signs that managers make mistakes when evaluating the future prospects of the firm.

Using a linear model of earnings expectations, Nissim and Ziv (2001) found a positive association between current dividend changes and future earnings changes and argued that previous studies were unsuccessful in uncovering this relation because were using the wrong model to control for the expected changes in earnings. Nissim and Ziv (2001) argue that when using a regression that controls for a linear form of mean reversion in earnings, dividend changes are positively related with future earnings changes.

Ap Gwilym et al. (2004) concluded that loss-making firms are more likely to reduce dividends compared to firms that remain profitable, although a loss is far from a guarantee that the dividend payment will be reduced. Interestingly, the study found that, due to the stronger culture of dividend payment in the UK compared to the US, there is a lower propensity to decrease dividends in the UK. The authors also found that the size of a loss and leverage are important factors in a firm's dividend policy. Higher levels of debt are consistent with a greater likelihood of a reduction in the distribution whilst also decreasing profitability in the future years. Profit margins before the loss year can also be considered a significant factor in dividend policy since firms with a lower margin are more likely to reduce dividends. Finally, some evidence is found that dividend reductions are a sign that future earnings will be lower than for non-reducing firms, although the statistical significance of these findings is quite low.

Grullon et al. (2005) later argued that the assumption of linear mean reversion process of earnings made by Nissim and Ziv (2001) is inappropriate, defending that the mean reversion process of earnings is highly nonlinear, thus considering that the positive correlation between dividend changes and future earnings changes obtained by Nissim and Ziv (2001) is spurious. Grullon et al. (2005) control the nonlinearity by using a model of unexpected earnings that corrects this problem by assuming the rate of mean reversion and coefficient of autocorrelation as nonlinear. After controlling for the nonlinear patterns in the behaviour of earnings, these authors show that dividend changes contain no information about future earnings changes. The authors also evidence that dividend changes are negatively correlated with future changes in profitability and research whether including dividend changes improves out-of-sample earnings forecasts. They find that models that include dividend changes do not outperform those that do not include them.

Hussainey and Aal-Eisa (2009), employing a methodology very similar to DeAngelo et al. (1996), examine whether voluntary disclosure and dividends signal future earnings for decline earnings growth firms. The authors examine the behaviour of 33 non-financial UK firms after a decline of their sustained earnings growth, finding that increasing dividends does not convey relevant information about future earnings for decline earnings growth firms. However, based on the disclosure signalling theory, it is also evidenced that increasing levels of forward-looking information in annual reports can be an important mechanism for signalling future earnings for firms. Also focused in the UK, Bozos et al. (2011) test the dividend signalling hypothesis and the interaction of earnings and dividends under both steady and adverse economic conditions. The authors document 
positive and significant average abnormal stock price returns around the dividend/earnings announcements and also find a significant interaction between economic conditions and the information content of dividends.

More recently, Liu and Chen (2015) use an updated model that fixes many of the downfalls of the models previously used. The simultaneous-equation model employs an equation that allows the model to regress current dividend changes on future earnings changes and at the same time control for other motives of dividend changes as well. They also find evidence that managers also change dividends for signalling previous earnings changes and for catering to dividend clienteles.

In sum, there is an extensive literature on the topic of the dividend policy but still no conclusive answer about the informative power of dividends and their connection with future earnings growth. The more recent studies seem to go against the signalling hypothesis and behavioural finance has been increasingly used as a way to provide an answer to the dividend puzzle. The key seems to reside in explaining the biases behind managers and investors that lead to the establishment of a dividend policy. In fact, another criticism that can be made to the literature is that it focused too much on the role of managers, when they are only half of the puzzle. Investors have an appetite for dividends that seems difficult to justify and few studies focused on their role.

\section{Methodological and data considerations}

\subsection{Methodology}

The simultaneous equation model is supposed to be superior to the simple OLS estimation run by the linear model of earnings expectations since it fixes the mutually endogenous problem between dividend changes and future earnings changes. The mutually endogenous problem exists because the manager's expectations of future profitability can influence dividends and so changes in dividends might also influence future profitability by affecting the capital structure of firms. The endogenous problem is thus related to both the dividend changes and future profitability and their relationship so a stronger and more accurate econometric model is required to test the dividend signalling theory.

The present paper tests the dividend signalling hypothesis by examining how current dividend changes are influenced by future earnings changes. By running the simultaneous-equation model we incorporate an equation that lets us regress current dividend changes on future earnings changes while controlling for other motives of dividend changes as well. The future earnings do not change because of dividends, it is the opposite. The models that we implement in our study use actual future earnings changes as we do not have access to forecasted future earnings changes but considering that managers have access to insider information, actual future earnings should be positively related to forecasted earnings.

Section 4 of this paper will provide the analysis of the results of the model but it is important to understand exactly the differences between what we are testing. First and foremost we analyse the results obtained with a linear model of earnings expectations, where there is a relation between dividend changes and future earnings changes: 


$$
\begin{aligned}
R \Delta D I V_{0}= & \alpha_{0}+\alpha_{1}\left[\left(E_{T}-E_{T-1}\right) / B_{-1}\right]+\alpha_{2} P R \Delta F C F D_{-1} \times R \Delta F C F_{-1} \times N R \Delta Q D_{-1} \\
& \times R \Delta Q_{-1}+\alpha_{3} N R \Delta F C F D_{-1} \times R \Delta F C F_{-1} \times P R \Delta Q D_{-1} \times R \Delta Q_{-1}+\alpha_{4} R \Delta E_{-1} \\
& +\alpha_{5} N D D i v P_{0} \times R \Delta \operatorname{DivP}_{0}+\alpha_{6} P D D i v P_{0} \times R \Delta D i v P_{0}+\mu r
\end{aligned}
$$

where $E_{t}$ is earnings before extraordinary items in year $t$ (year 0 is the event year); $B_{-1}$ is the book value of equity at the end of year $-1 ; R \Delta D I V_{0}$ is the annual percentage change in the cash dividend payment in year $0 ; R \triangle F C F_{-1}=\left(F C F_{-1}-F C F_{-2}\right) / F C F_{-2}$ is the rate of change in free cash flow in year $-1 ; R \Delta Q_{-1}=\left(Q_{-1}-Q_{-2}\right) / Q_{-2}$ is the rate of change in Tobin's $\mathrm{Q}$ in year $-1 ; P R \triangle F C F D_{-1}\left(N R \triangle F C F D_{-1}\right)$ is a dummy variable that equals 1 for positive $R \triangle F C F_{-1}$ and 0 otherwise; $P R \triangle Q D_{-1}\left(N R \triangle Q D_{-1}\right)$ is a dummy variable that equals 1 for positive $R \Delta Q_{-1}$ and 0 otherwise; $R \Delta E_{-1}=\left(E_{-1}-E_{-2}\right) / E_{-2}$ is the rate of change in earnings in year $-1 ; R \Delta \operatorname{Div} P_{0}=\left(\operatorname{Div} P_{0}-\operatorname{Div} P_{-0}\right) / \operatorname{Div} P_{-1}$ is the contemporaneous dividend premium change rate; $P D \operatorname{Div} P_{0}\left(N D D i v P_{0}\right)$ is a dummy variable that equals 1 if $\mathrm{R} \triangle \mathrm{DivP} 0$ is positive and 0 otherwise. According to the signalling hypothesis $\alpha_{1}$ and $\alpha_{2}$ should be positive and $\alpha_{3}$ should be negative.

Equation (1) is also the dividend change equation in the simultaneous-equation model but we first begin by running the OLS estimation and analysing the obtained results before introducing the two-stage least square regression and the second equation, the future earnings change equation, both on the linear and nonlinear forms.

As explained, the dividend-signalling hypothesis states that managers change dividends in order to signal earnings prospects. Firms that predict higher (lower) earnings prospects are expected to pay out more (less) dividends and this implies that dividend changes depends on future earnings changes. Equation (1) is used in the OLS estimation and represents that hypothesis where dividend changes are regressed on future equity-scaled earnings changes, thus the name 'dividend change equation'. In order for the theory to prove true the coefficient of future equity-scaled earnings changes should be positive and significant. But this equation contains other variables in order to control for the additional motives that lead managers to change dividends, namely:

a Reduction of agency costs - managers may want to increase dividends in order to reduce the costs emanating from the fact that the relation between managers and investors is not symmetrical. Managers have inside information and their own motivations while investors do not have access to this information and want to obtain return on their investments.

The free cash flow hypothesis states that managers may increase dividends by using surplus cash that went unused after all positive NPV projects were financed in order to reduce these agency costs. In order to hold this theory in the model then dividends must increase (decrease) as free cash flow increases (decreases) and investment opportunities decrease (increase). Thus, the model adds a variable for positive (negative) changes in preceding free cash flow and negative (positive) changes in preceding investment opportunity set and the coefficient must be positive in order to validate the theory. The free cash flow is calculated as EBITDA less income taxes, changes in working capital and Capex.

To measure the investment opportunity set it is used Tobin's Q. Adam and Goyal (2008) show that it has higher information content with respect to investment opportunities than other measures such as the market-to-book equity ratio, the earnings-price ratio and the ratio of capital expenditures over the net book value of 
plant, property and equipment. Tobin's Q is thus calculated as the ratio between market capitalisation (plus current liabilities and long term debt) and total assets (plus current liabilities and long term debt) (Damodaran, 2006).

b Confirming the persistence of previous earnings changes - managers may want to manipulate the dividend policy in order to validate their belief that earnings will continue to increase (decrease) or remain constant with previous financial exercises. To test this theory, equation (1) includes the rate of change in earnings one year before the dividend-change event year and its coefficient should be positive if the theory is to hold true.

c Catering to dividend clienteles - some managers use the dividend policy as a sort of ritual between themselves and investors. For them it is important to keep a specific dividend policy constant despite the firm's future earnings prospects. Managers may also set an attractive dividend policy in order to attract new investors and gain market benefits as investors naturally pay more for firms that pay higher cash dividends.

In order to test this hypothesis, equation 1 includes the contemporaneous changes in the dividend premium $\left(R \Delta D i v P_{0}\right)$ which allows for asymmetric effects of dividend premium increases and decreases. Increasing (decreasing) the dividend premium should increase (decrease) dividend levels. Thus, the dividend premium (DivP) is used to measure the dividend preference in the market. In order to compute the dividend premium of European firm we followed Ferris et al. (2009) methodology. Ferris et al. (2009) set a requirement of ten dividend paying and ten non-dividend paying firms for each country in the sample in order to guarantee that the dividend premiums are computed based on a minimum number of firms. We performed the same calculations, obtaining values for the dividend premiums for different countries and in different years with the exception of Estonia, Luxembourg and Czech Republic due to the lack of sufficient financial information in the database Amadeus. We did not remove them from the sample however since both Luxembourg and Estonia was each represented by only one firm and Czech Republic by three firms.

After presenting the results for the OLS estimation for the dividend change equation we turn to the simultaneous-equation model and the two-stage least square method. Stage one is performed by running the regression of the future earning change equation (linear and nonlinear) and obtaining the fitted values for that regression. Once the software has calculated the fitted values for that first regression it runs the second step, that is, a regression using the dividend change equation alongside the previously calculated fitted values. We applied the linear model established by Nissim and Ziv (2001):

$$
\left(E_{T}-E_{T-1}\right) / B_{-1}=\beta_{0}+\beta_{1} R \Delta D I V_{0}+\beta_{2} R O E_{T-1}+\beta_{3} C E_{0}+\varepsilon_{T}
$$

where $C E_{0}$ represents current earnings, computed as $C E_{0}=\left(E_{0}-E_{-1}\right) / B_{-1}$.

Grullon et al. (2005) modify Nissim and Ziv's model for the nonlinear earnings process by using a modified partial adjustment model proposed by Fama and French (2000). This model controls for the nonlinearities in the relation between future earnings changes and lagged earnings levels and changes. Thus, following Grullon et al. (2005), equation (3) represents the future earnings change equation in its nonlinear form: 


$$
\begin{aligned}
{\left[\left(E_{T}-E_{T-1}\right) / B_{-1}\right]=} & \beta_{0}+\beta_{1} R \Delta D I V_{0}+\left(\gamma_{1}+\gamma_{2} N D F E D_{0}+\gamma_{3} N D F E D_{0} \times D F E_{0}\right. \\
& \left.+\gamma_{4} P D F E D_{0} \times D F E_{0}\right) \times D F E_{0}+\left(\lambda_{1}+\lambda_{2} N C E D_{0}+\lambda_{3} N C E D_{0}\right. \\
& \left.\times C E_{0}+\lambda_{4} P C E D_{0} \times C E_{0}\right) \times C E_{0}+\varepsilon_{t}
\end{aligned}
$$

In sum, by combining the future earnings change equation with the dividend change equation in a simultaneous equation framework using of a two-stage least square regression results should be more accurate.

Section 4.2 also presents the results for the relation between dividend changes and future asset-scaled earnings changes, where $\left(E_{T}-E_{T-1}\right) / B_{-1}$ in equations (1) to (3) is replaced by $\left(\mathrm{ROA}_{T}-\mathrm{ROA}_{\mathrm{T}-1}\right)$ and $\mathrm{ROE}_{\mathrm{T}-1}$ in equation (2) is replaced by $\mathrm{ROA}_{\mathrm{T}-1}$.

\subsection{Data}

Our sample contains European non-financial firms with a minimum of five years of sustained earnings growth before the first year of decline in earnings. This means that firms with more than five years of sustained earnings growth are also included in the sample. Amadeus database has information about firms for a period of ten years, from 2005 to 2014, so it would be difficult to find a considerable sample size if the restrictions were very strict. There are firms in the sample that experienced a period of growth starting before 2005 but these are special cases of firms that had their financial information available to us in Datastream or through their annual reports. So, for the gathering of all the necessary data it was also necessary to use the Thompson Datastream database since Amadeus does not provide information about dividends. The sample only includes firms that are dividend-paying firms so all firms that have had five years or more of sustained growth but didn't paid dividends were removed.

The study follows the rules of an event study, with a division in three stages: pre-event, on-the-event and post-event. The pre-event comprises the five years before the first year of decline in dividends and the data relative to those years will be important in computing the abnormal future earnings of the sample firms using the growth-adjustment model (later in Section 5.3). The on-the-event represents the first year of decline, the so-called year 0 , and data relative to this year will be important in testing whether the signalling hypothesis holds because it is the dividend policy set by the managers in this year that could very well reflect what will happen to the sample firms in the following years. Finally, the post-event comprises the two years after the first year of decline and the information concerning those years will be fundamental in testing whether what was predicted by the dividend policy was in fact correct or not. For this reason, firms that had five or more years of consecutive earnings growth with year 0 being 2014 or 2015 were immediately removed from the sample as we did not have sufficient information about years +1 and +2 . Finally, we also removed firms with five or more years of sustained earnings growth but without complete information about other key figures (e.g., return on assets, return on equity, book value, etc.) in Amadeus or we could not find their annual reports in the web. To eliminate the influence of outliers we truncated two of the top and two of the bottom firms from the dividend changes distribution. This was done because the sample size was not big enough to avoid being influenced by outlier firms. 
Table 1 Descriptive statistics of key characteristics of the sample firms for dividend-decrease, dividend-increase and dividend-no-change events

\begin{tabular}{|c|c|c|c|c|c|c|}
\hline \multicolumn{7}{|c|}{ Panel A: dividend decreases } \\
\hline & Mean & Stand. dev. & $5 \%$ & $50 \%$ & $95 \%$ & $N$ \\
\hline $\mathrm{R} \Delta \mathrm{DIV}$ & $-47.89 \%$ & $42 \%$ & $1 \%$ & $9 \%$ & $27 \%$ & 9 \\
\hline MV (th. €) & 516,420 & 449,035 & 9,385 & 100,956 & 293,364 & 9 \\
\hline $\mathrm{M} / \mathrm{B}$ & 3.73 & 5.03 & 0.11 & 1.13 & 3.29 & 9 \\
\hline ROE (\%) & 21.59 & 12.06 & 0.25 & 2.71 & 7.88 & 9 \\
\hline ROA (\%) & 10.14 & 5.31 & 0.11 & 1.19 & 3.47 & 9 \\
\hline \multicolumn{7}{|c|}{ Panel B: dividend increases } \\
\hline & Mean & Stand. dev. & $5 \%$ & $50 \%$ & $95 \%$ & $N$ \\
\hline $\mathrm{R} \Delta \mathrm{DIV}$ & $39.63 \%$ & $68 \%$ & $1 \%$ & $15 \%$ & $45 \%$ & 64 \\
\hline MV (th. €) & $1,276,908$ & $1,876,775$ & 14,710 & 421,955 & $1,226,137$ & 64 \\
\hline $\mathrm{M} / \mathrm{B}$ & 2.87 & 2.39 & 0.02 & 0.54 & 1.56 & 64 \\
\hline ROE (\%) & 22.16 & 11.46 & 0.09 & 2.58 & 7.49 & 64 \\
\hline ROA (\%) & 12.16 & 9.25 & 0.07 & 2.08 & 6.04 & 64 \\
\hline \multicolumn{7}{|c|}{ Panel C: no changes } \\
\hline & Mean & Stand. dev. & $5 \%$ & $50 \%$ & $95 \%$ & $N$ \\
\hline $\mathrm{R} \Delta \mathrm{DIV}$ & $0 \%$ & $0 \%$ & $0 \%$ & $0 \%$ & $0 \%$ & 3 \\
\hline MV (th. €) & 348,902 & 384,242 & 3,011 & 86,389 & 251,033 & 3 \\
\hline $\mathrm{M} / \mathrm{B}$ & 4.96 & 5.99 & 0.05 & 1.35 & 3.92 & 3 \\
\hline ROE (\%) & 29.89 & 26.46 & 0.21 & 5.95 & 17.29 & 3 \\
\hline ROA (\%) & 17.34 & 19.07 & 0.15 & 4.29 & 12.46 & 3 \\
\hline
\end{tabular}

Notes: R $\triangle \mathrm{DIV}$ denotes the annual dividend change rate. $\mathrm{MV}$ is the market value and it is equal to calendar year-end stock price multiplied by shares outstanding. M/B represents the ratio of market value to book value of equity at the end of the dividend event year. ROE and ROA represent the return on equity and return on assets respectively. $\mathrm{N}$ represents the sample size.

The resulting sample contains 76 firms from 16 European countries, with firms from Germany, Great Britain and Spain representing almost $44 \%$ of the sample. Table 1 provides descriptive statistics about the sample, where it can be observed that 64 firms increased their dividends in year 0 (the year where earnings decline), while nine decreased their dividends and only three made no changes to their policy.

From the data we can conclude that: dividend-increasing firms have the highest market value ( $€ 1,277$ million vs. $€ 516$ million) which means that they are larger than the dividend-decreasing firms and those that do not change their dividend policy. This conclusion is also consistent with previous studies such as Grullon et al. (2005) and Liu and Chen (2015). Firms that increase dividends are also more profitable than those that do not as their average ROE and ROA are higher (respectively, 22.16 vs. 21.59 and 12.16 vs. 10.14) although the differences in these numbers are not as dramatic as in the market value. 


\section{Empirical results}

\subsection{Dividend changes and future equity-scaled earnings changes}

In this section we will use the equations for both the dividend change equation [equation (1)] and future earnings change equations [equations (2) and (3)] in their respective linear and nonlinear forms when analysing the relation between dividend changes and future equity-scaled earnings changes. In order to run the dividend change equation we computed the yearly dividend premium for the countries in our sample following Ferris et al. (2009). That data is available upon request, with the average global dividend premium being around $6.7 \%$, with a maximum of $8.8 \%$ in 2012 and a minimum of $3 \%$ in 2009 . Table 2 presents the results for the OLS regression of the dividend change equation.

Table 2 Simple OLS regression of the dividend change equation (dividend changes and future equity-scaled earnings changes)

\begin{tabular}{|c|c|c|c|c|c|c|c|}
\hline \multicolumn{4}{|c|}{$T=1$} & \multicolumn{4}{|c|}{$T=2$} \\
\hline & Coefficient & Standard & rror & & Coefficient & Standard & error \\
\hline Intercept & 0.113 & 0.136 & & Intercept & 0.109 & 0.136 & \\
\hline$\alpha_{1}$ & 0.174 & 0.295 & & $\alpha_{1}$ & -0.067 & 0.206 & \\
\hline$\alpha_{2}$ & 0.419 & 0.440 & & $\alpha_{2}$ & 0.426 & 0.441 & \\
\hline$\alpha_{3}$ & -0.065 & 0.367 & & $\alpha_{3}$ & -0.087 & 0.366 & \\
\hline$\alpha_{4}$ & 0.393 & 0.113 & $* * *$ & $\alpha_{4}$ & 0.389 & 0.114 & $* * *$ \\
\hline$\alpha_{5}$ & -0.395 & 0.698 & & $\alpha_{5}$ & -0.437 & 0.698 & \\
\hline$\alpha_{6}$ & -0.013 & 0.129 & & $\alpha_{6}$ & -0.010 & 0.133 & \\
\hline R-squared & 0.161 & R-squared & 0.158 & & & & \\
\hline
\end{tabular}

Notes: $* \mathrm{p}<0.10 ; * * \mathrm{p}<0.05 ; * * * \mathrm{p}<0.01$. This table reports the OLS estimated regression of the dividend change equation [equation (1)] for the subsequent two years after the dividend-change event year $(\mathrm{T}=1$ and 2$)$ :

The coefficient on future equity-scaled earnings changes $\left(\alpha_{1}\right)$ is positive $(0.174)$ but statistically insignificant, whereas for the second year the coefficient is negative $(-0.067)$ and also insignificant. These results indicate that dividends are not adjusted based on long-term earnings prospects and go against the signalling hypothesis. If we look at the coefficients of the control variables, even though $\alpha_{2}$ and $\alpha_{3}$ are, respectively, positive and negative as expected by the free cash flow hypothesis, they are both insignificant. This indicates that surplus cash and investment opportunities are not determinants of dividend changes. However, when we look at $\alpha_{4}$ and the first year after year 0 , the coefficient for preceding earnings changes is positive $(0.393)$ and significant at the $1 \%$ level. The same happens for $\mathrm{T}=2$ and these results support the previous earnings hypothesis and strongly suggest that managers adjust dividends to reflect past earnings changes. However, if we look at $\alpha_{5}$ and $\alpha_{6}$ we can see that all the coefficients for $\mathrm{T}=1$ and $\mathrm{T}=2$ are negative and insignificant which goes against the catering hypothesis and strongly suggests that managers do not change dividends according to the investors' preference for dividends. 
Table 3 First stage of the 2SLS regression using the future earnings change equation in linear and nonlinear forms (dividend changes and future equity-scaled earnings changes)

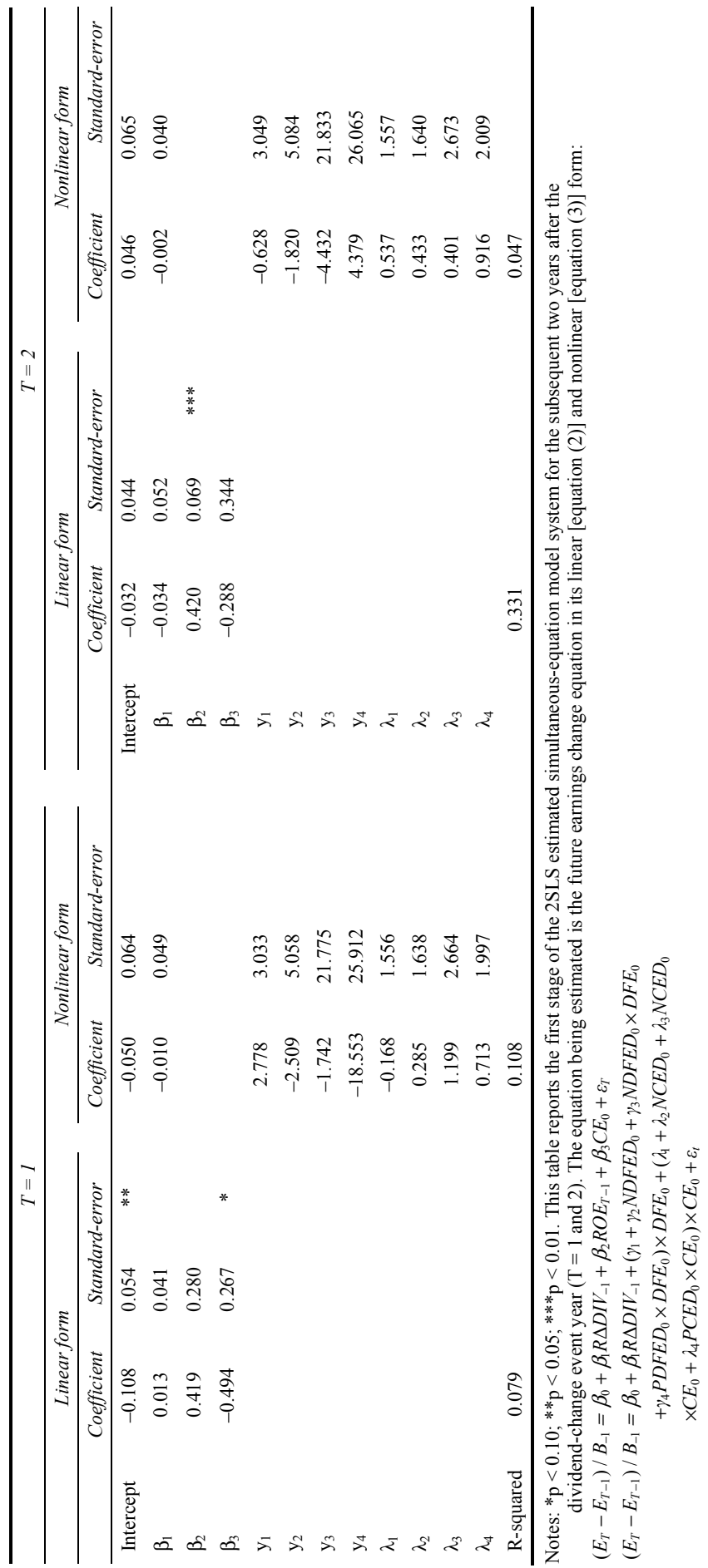


Table 4 Second stage of the 2SLS regression using the dividend change equation in its linear and nonlinear forms (dividend changes and future equity-scaled earnings changes)

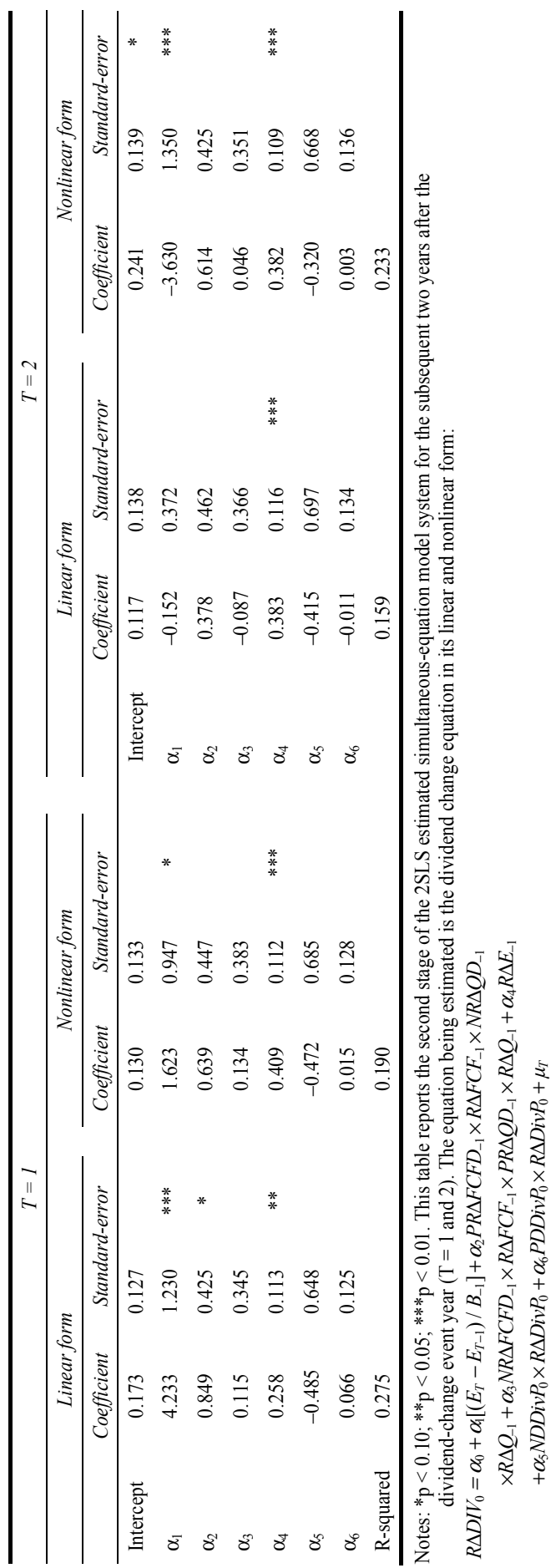


Next, we present the regression results for the simultaneous-equation model in its linear and nonlinear forms. The first stage of the 2SLS method is the regression of the future earnings change equation in its linear and nonlinear forms [respectively, equation (2) and equation (3)]. The results of the regression for the future earnings change are presented in Table 3.

$$
\begin{aligned}
\Delta D I V_{0}= & \alpha_{0}+\alpha_{1}\left[\left(E_{T}-E_{T-1}\right) / B_{-1}\right]+\alpha_{2} P R \Delta F C F D_{-1} \times R \Delta F C F_{-1} \times N R \Delta Q D_{-1} \\
& \times R \Delta Q_{-1}+\alpha_{3} N R \Delta F C F D_{-1} \times R \Delta F C F_{-1} \times P R \Delta Q D_{-1} \times R \Delta Q_{-1}+\alpha_{4} R \Delta E_{-1} \\
& +\alpha_{5} N D D i v P_{0} \times R \Delta D i v P_{0}+\alpha_{6} P D D i v P_{0} \times R \Delta D i v P_{0}+\mu_{T}
\end{aligned}
$$

By looking at the results of the regression we can see that the coefficients for $\beta_{1}$ are positive for year $\mathrm{T}=1(0.013)$ and negative for year $\mathrm{T}=2(-0.034)$ but these coefficients are both statistically insignificant. However, when we look at the control variables we reach interesting conclusions. If we observe the coefficient for $\beta_{2}$ we find that although it is insignificant for $\mathrm{T}=1$, it is positive and significant for year $\mathrm{T}=2$. This means that for the second year after the event year the level of ROE for the previous year helps to explain the earnings changes for the next year. It can be argued that there is some merit for Nissim and Ziv's theory that ROE can be an important predictor of future earnings changes. For the coefficient $\beta_{3}$ the values are negative and insignificant for year $T=2$. However, when we look at year $\mathrm{T}=1$ they remain negative but significant at the $10 \%$ level showing some signs of autocorrelation between the earnings of year 1 and those of year 0 . Since the $\mathrm{p}$-value is not that high and the same does not happen in year $\mathrm{T}=2$ we must take these conclusions with caution.

The results for the regression of the future earnings change equation in its nonlinear form are simple to analyse as all coefficients are insignificant either in $\mathrm{T}=1$ and $\mathrm{T}=2$. The most important coefficient however is $\beta_{1}$, which is the coefficient on the dividend changes and it is negative and insignificant in both years. These results are consistent with the linear model so we can confirm that neither the negative effect of dividend changes based on the pecking order theory nor the positive effect based on the agency cost theory is confirmed.

Having run the regression for the future earnings change equation it is time for the second stage of the 2SLS regression which focuses on the dividend change equation [equation (1)], where the fitted values from the first regression are used in this second stage. Table 4 presents the results for this step of the simultaneous-equation model.

In the dividend change equation the coefficient on future equity-scaled changes $\left(\alpha_{1}\right)$ in the linear model system is positive (4.233) and significant for $\mathrm{T}=1$, but negative and insignificant in $T=2$. These results indicate that the dividend policy is changed based on future earnings prospects. When managers forecast earning levels for one year from now they signal this information to investors by changing the dividend policy. This is strong evidence in favour of the dividend signalling hypothesis. If we look at the control variables only $\alpha_{2}$ and $\alpha_{4}$ provide significant results. The coefficient $\alpha_{2}$ is positive and significant in year $T=1$. This result indicates that surplus cash is an important factor in determining the dividend policy and supports the free cash flow hypothesis. The coefficient on the preceding earnings changes $\left(\alpha_{4}\right)$ is also significant and positive in $T=1$ and $\mathrm{T}=2$. This result supports the previous earnings hypothesis and indicates that managers change dividends not only to signal future earnings prospects but also to reflect past earnings changes. Overall, the results of the 2SLS regression show that dividend 
changes cannot serve as a tool to predict firm equity-scaled earnings prospects even if dividend changes can be used by managers as a signalling tool.

Table 4 includes the results for the second stage of the 2SLS regression in the nonlinear model. The coefficient for $\alpha 1$ provides the same conclusion as in the linear model, being positive (1.623) and significant at the $10 \%$ level for $\mathrm{T}=1$. The biggest difference is for year $\mathrm{T}=2$ as the coefficient is still negative but this time highly significant whereas it was negative but insignificant for the linear model. Again, these conclusions support the dividend signalling hypothesis. As for the control variables, the only significant coefficient is $\alpha 4$. This coefficient is also positive and significant in the linear model in both years so the results coincide. The results for the nonlinear model support the previous earnings hypothesis indicating that managers change dividends not only to signal future earnings prospects but also to reflect past earnings changes.

\subsection{Dividend changes and future asset-scaled earnings changes}

This section replicates the OLS estimation and the simultaneous-equation model making a slight change in the variables in order to gain more evidence towards the dividend signalling hypothesis. Thus, since the dividend signalling hypothesis does not state precisely what type of information managers want to convey when they change the dividend policy (future income or future profitability), there could possibly exist other performance measures more correlated to dividend changes. Such is the case of ROA or asset-scaled earnings which is a measure widely used to capture firm performance. ROA can be considered a good measure of firms' performance because unlike equity-scaled earnings it is not sensitive to changes in capital structure and it is not affected by special items such as non-recurring items reported before taxes, income taxes or accounting for minority interests. This method has been widely used in previous studies such as the ones from Fama and French (2000), Nissim and Ziv (2001), Grullon et al. (2005) and Liu and Chen (2015).

Table 5 Simple OLS Regression of the dividend change equation (dividend changes and future asset-scaled earnings changes)

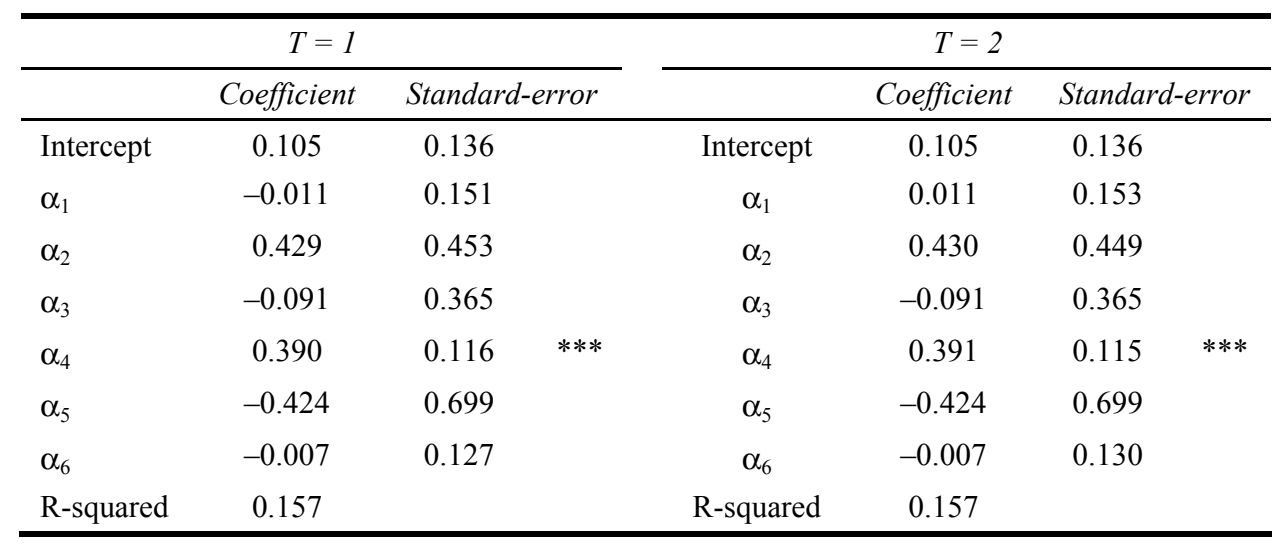

Notes: ${ }^{*} \mathrm{p}<0.10 ;{ }^{* *} \mathrm{p}<0.05 ; * * * \mathrm{p}<0.01$. This table reports the OLS estimated regression of the dividend change equation [equation (1)] for the subsequent two years after the dividend-change event year $(\mathrm{T}=1$ and 2$)$. 
Table 6 First stage of the 2SLS regression using the future earnings change equation in its linear form (dividend changes and future equity-asset earnings changes)

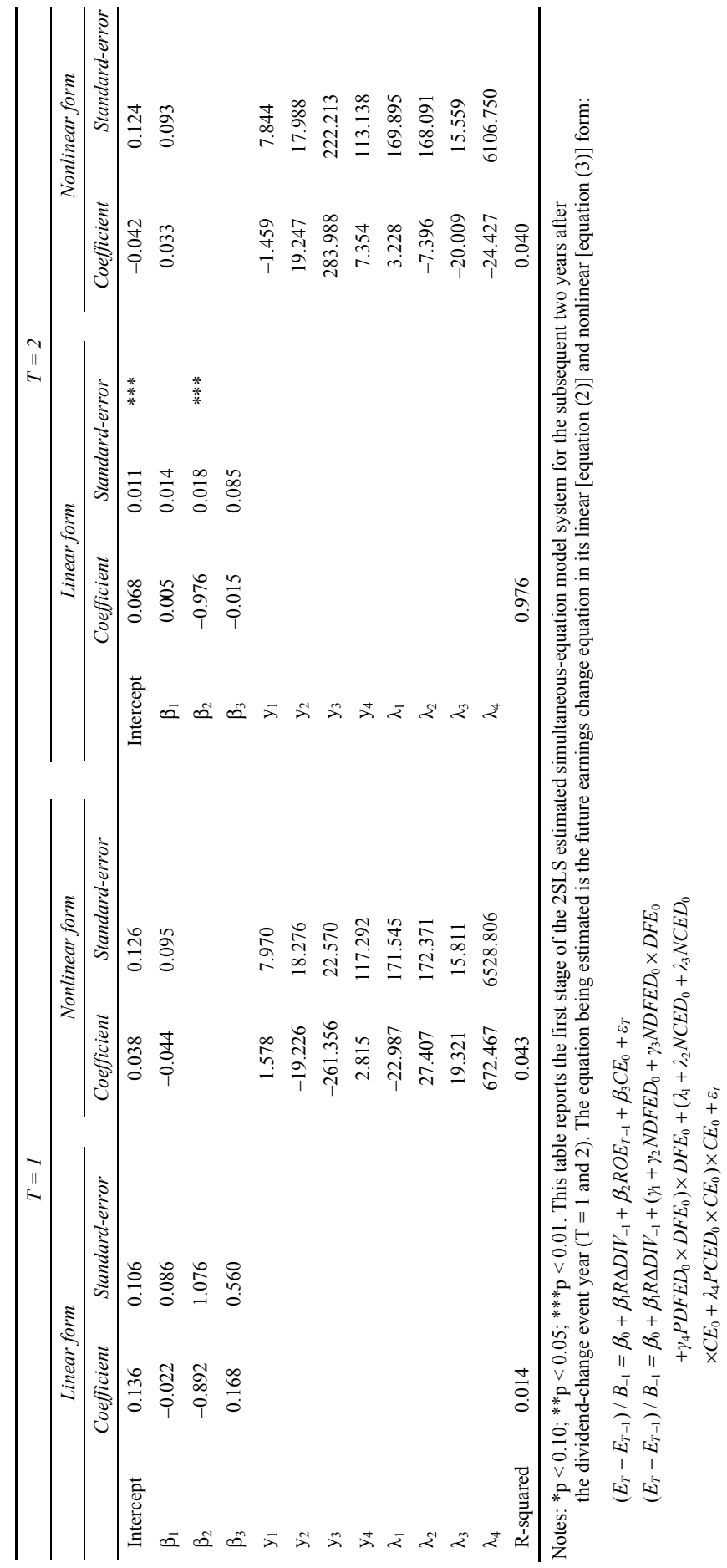


Table 7 Second stage of the 2SLS regression using the dividend change equation in its linear and nonlinear form (dividend changes and future asset-scaled earnings changes)

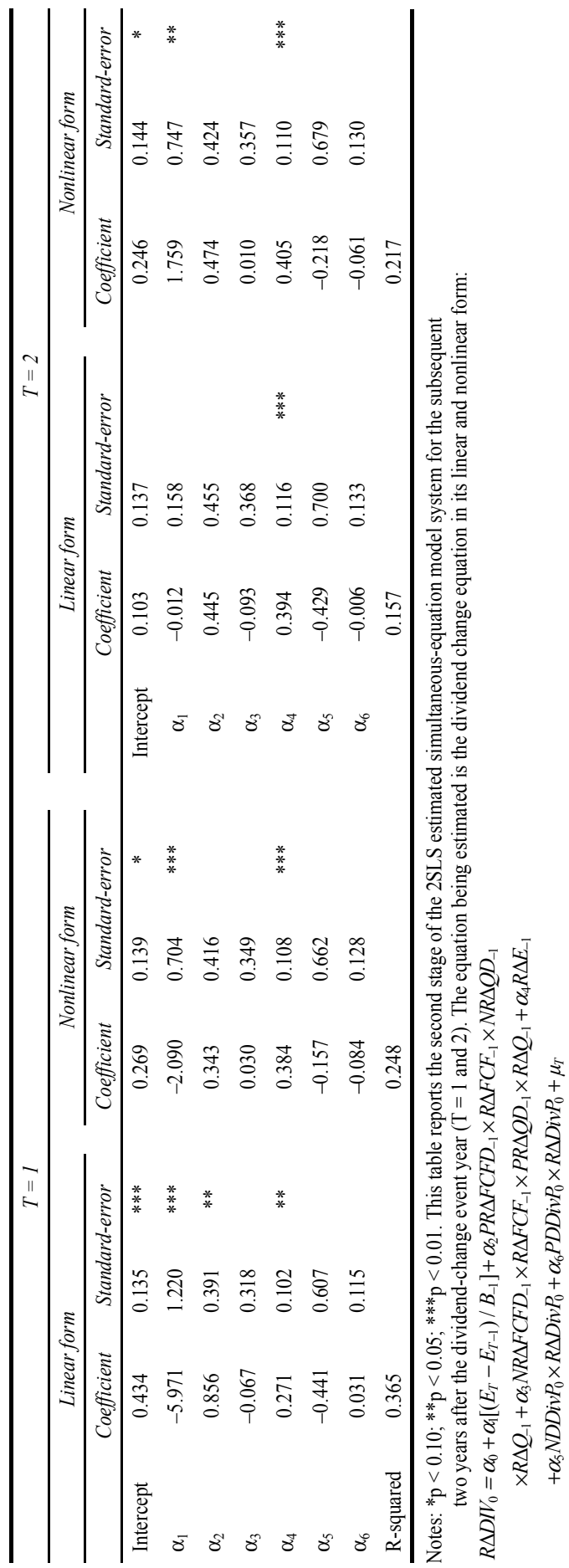


Table 5 presents the results for the OLS estimation of the dividend change equation, where the only significant coefficient is $\alpha_{4}$ and the fact that both $\alpha_{1}$ are highly insignificant suggests that the signalling of information about the change in ROA in the future is not the main objective of changes in the dividend policy. As in the previous section, $\alpha_{2}$ and $\alpha_{3}$ are both insignificant, so these results do not support the free cash flow hypothesis. The catering hypothesis also finds little support since $\alpha_{5}$ and $\alpha_{6}$ are always insignificant. However, it is interesting to note that $\alpha_{4}$ are positive and extremely significant for both years. This is consistent with the findings from the previous section which support the previous earnings hypothesis where managers change dividends to reflect past earnings changes.

$$
\begin{aligned}
\Delta D I V_{0}= & \alpha_{0}+\alpha_{1}\left[\left(E_{T}-E_{T-1}\right) / B_{-1}\right]+\alpha_{2} P R \Delta F C F D_{-1} \times R \Delta F C F_{-1} \times N R \Delta Q D_{-1} \\
& \times R \Delta Q_{-1}+\alpha_{3} N R \Delta F C F D_{-1} \times R \Delta F C F_{-1} \times P R \Delta Q D_{-1} \times R \Delta Q_{-1}+\alpha_{4} R \Delta E_{-1} \\
& +\alpha_{5} N D D i v P_{0} \times R \Delta \operatorname{DivP}_{0}+\alpha_{6} P D D i v P_{0} \times R \Delta D i v P_{0}+\mu_{T}
\end{aligned}
$$

Next, it is run the two-stage least square model in its linear form. We will follow the same steps as in the previous section and start by running the regression of the future earnings change equation and after that we will present the results for the second stage of the 2SLS regression which focuses on the dividend change equation.

Table 6 presents the results of the regression of the future earnings change equation adapted to test the relationship between dividend changes and future asset-scaled earnings changes. All coefficients with the exception of $\beta_{2}$ are insignificant. The coefficient that measures the predictive ability of dividend changes on ROA changes $\left(\beta_{1}\right)$ is negative for $\mathrm{T}=1$ and positive for $\mathrm{T}=2$ but insignificant in both years. These findings are not consistent with the results of Grullon et al. (2005) and Liu and Chen (2015) for the US. In both their studies the $\beta_{1}$ for $T=1$ was indeed negative but significant while the results for $\mathrm{T}=2$ are consistent with our findings. As for the control variables only $\beta_{2}$ is significant at the $1 \%$ level but only for year $\mathrm{T}=2$. The coefficient is negative $(-0.976)$ which means that for the second year after the event year an increase in the ROA levels for year $\mathrm{T}=1$ indicates a decrease on the level of ROA changes from year 2 to 1 . These findings are consistent with Grullon et al. (2005) and Liu and Chen (2015).

Table 6 also presents the results for the nonlinear form of the future earnings change equation. The test of the predictive ability of dividend changes on ROA changes using the nonlinear model is consistent with the linear model for $\beta_{1}$ as the coefficient is negative for $\mathrm{T}=1$ and positive for $\mathrm{T}=2$ but always statistically insignificant. All other coefficients are insignificant.

We then proceed to the second stage of the 2SLS regression where the fitted values from the regression of the future earnings change equation are used to run the regression on the dividend change equation. Table 7 presents the results for the regression of the dividend change equation taking into consideration the ROA changes. The results for the coefficients of the dividend change equation using the simultaneous-equation analysis are consistent with those from previous studies. The $\alpha_{1}$ are negative for both years but this time the coefficient is extremely significant for year $\mathrm{T}=1$ while insignificant for year $\mathrm{T}=2$. These results are contrary to those found in the previous section, suggesting that dividend changes do not happen for the purpose of signalling changes in ROA in the future. One possible explanation is provided by Liu and Chen (2015) which state that equity investors, as accepters of dividends and direct signalling targets to managers, are 
more concerned about equity-scaled earnings changes than asset-scaled earnings changes and are willing to pay more for stocks of firms with better asset-scaled earnings prospects. So, it makes sense that when setting the dividend policy managers are more preoccupied with signalling information relative to equity-scaled earnings changes than asset-scaled earnings changes.

Looking at the control variables we can identify two significant coefficients $\left(\alpha_{2}\right.$ and $\alpha_{4}$ ). The positive coefficient (0.856) for $\alpha_{2}$ favours the free cash flow hypothesis and the also positive coefficient for $\alpha_{4}$ gives support to the previous earnings changes hypothesis, coinciding with the findings for the equity-scaled earning changes model.

Table 7 includes the results for the second stage of the 2SLS regression using the nonlinear model, which are similar to those found when using the linear model. The coefficient $\alpha_{1}$ is negative $(-2.090)$ for year $\mathrm{T}=1$ and extremely significant. This coincides with the results for the linear model and provides further evidence that the purpose behind dividend changes is not to signal changes in ROA in the future.

As for the control variables, again the nonlinear model coincides with the results from the linear model as only $\alpha_{4}$ are significant for both years. This result provides further evidence that managers take into consideration previous earning changes when setting the dividend policy of their firm.

\section{Robustness tests}

In this section we present the main results of some robustness tests made to verify the findings from the previous section and see if they hold up to alternate specifications. Specifically, it is analysed the relationship between dividend changes and ROE levels, dividend changes and ROA levels and, lastly, dividend changes and abnormal earnings. For brevity reasons, only the general conclusions are presented, being the detailed empirical results available upon request.

\subsection{Dividend changes and ROE levels}

\subsubsection{The model}

For this first robustness test it is estimated the following ROE linear and nonlinear model systems:

a ROE linear model system:

Dividend change equation

$$
\begin{aligned}
R \Delta D I V_{0}= & \alpha_{0}+\alpha_{1} R O E_{T}+\alpha_{2} P R \Delta F C F D_{-1} \times R \Delta F C F-1 \times N R \Delta Q D_{-1} \times R \Delta Q_{-1} \\
& +\alpha_{3} N R \Delta F C F D_{-1} \times R \Delta F C F-1 \times P R \Delta Q D_{-1} \times R \Delta Q_{-1}+\alpha_{4} R \Delta E_{-1} \\
& +\alpha_{5} N D D i v P_{0} \times R \Delta D i v P_{0}+\alpha_{6} P D D i v P_{0} \times R \Delta D i v P_{0}+\mu_{T}
\end{aligned}
$$

Future earnings change equation

$$
R O E_{T}=\beta_{0}+\beta_{1} R \Delta D I V_{0}+\beta_{2} R O E_{T-1}+\beta_{3} C E_{0}+v_{1} M B_{-1}+v_{2} \text { Size }_{-1}+\varepsilon_{T}
$$


where $M B_{-1}$ is the log of the market-to-book ratio of equity in year -1 . Size $e_{-1}$ is the $\log$ of total assets in year -1 and all the remaining acronyms are the previously described.

b ROE nonlinear model system:

The dividend change equation is the same as (4) and the future earnings change equation is given by the following equation, where $D F E_{0}$ is equal to $R O E_{0}$ because the dependent variable in this equation is determined primarily by the ROE in year 0 :

$$
\begin{aligned}
R O E_{T}= & \beta_{0}+\beta_{1} R \triangle D I V_{0}+\left(\gamma_{1}+\gamma_{2} N D F D_{0}+\gamma_{3} N D F E D_{0}\right. \\
& \left.\times D F E_{0}+\gamma_{4} P D F E D_{0} \times D F E_{0}\right) \times D F E_{0}+\left(\lambda_{1}+\lambda_{2} N C E D_{0}+\lambda_{3} N C E D_{0}\right. \\
& \left.\times C E_{0}+\lambda_{4} P C E D_{0} \times C E_{0}\right) \times C E_{0}+v_{1} M B_{-1}+v_{2}{S i z e_{-1}}+\varepsilon_{T}
\end{aligned}
$$

The reason behind the choice of ROE as the dependent variable is related to the fact that according to the dividend signalling hypothesis firms with higher forecasted future earnings, be it ROE or ROA (as we will see further ahead), are more likely to have managers that set a more generous dividend policy towards investors when compared with firms with lower forecasted future earnings. In the same way, dividends changes can also have a positive or negative effect on future earnings levels.

As we had already done on the previous section, it were needed some special calculations before proceeding to the regressions. Specifically, we had to compute DFE0 and CE0 as their formulas are different for this model.

\subsubsection{Regression results}

Concerning the OLS regression [equation (4)] results we start seeing a pattern as the coefficient $\alpha_{4}$ is again the only one that is significant at the $1 \%$ level, presenting a positive sign. The previous earnings hypothesis receives additional support as these results coincide with the results from previous models.

By looking at the results from equation (5) we find consistency with previous findings as dividend changes cannot predict ROE levels. This conclusion can be obtained by looking at the coefficient $\beta_{1}$ and noticing that it is negative $(-0.004)$ and insignificant for $\mathrm{T}=1$ and positive (0.009) while also insignificant for $\mathrm{T}=2$. As for the control variables the only ones with explanatory power are $v_{1}$ for the year $\mathrm{T}=2$ as it is positive $\left(0.175\right.$ ) and extremely significant and $v_{2}$ again for the year $T=2$ (negative and significant). Regarding the nonlinear form, there is further indication that dividend changes cannot predict future ROE levels, since the $\beta_{1}$ coefficients for $\mathrm{T}=1$ and $\mathrm{T}=2$ are also insignificant.

Regarding the results for the second stage of the 2SLS regression that focuses on the dividend change equation [equation (4)], the coefficient $\alpha_{1}$ is negative and insignificant for the year $\mathrm{T}=1$, but positive (1.928) and significant for the year $\mathrm{T}=2$. The results for this coefficient in year $\mathrm{T}=1$ do not support the signalling hypothesis, however year $\mathrm{T}=2$ supports the dividend signalling hypothesis. As for the control variables only $\alpha_{4}$ is significant both years, presenting similar coefficients (0.388 and 0.385). Considering these results there is extremely strong evidence that managers take into consideration previous earnings changes when deciding the dividend policy. 
The results for the nonlinear regression of the dividend change equation are similar to those for the linear model since the coefficient $\alpha_{1}$ is insignificant and negative $(-0.298)$ for the year $\mathrm{T}=1$ while significant and positive (1.656) for the year $\mathrm{T}=2$. Other similar results occur for the coefficient $\alpha 4$ as it is extremely significant and positive for year $\mathrm{T}=1$ and also extremely significant and positive for year $\mathrm{T}=2$. Similarly to some of the previous models, there is evidence of the free cash flow hypothesis in year $\mathrm{T}=2$ since $\alpha_{2}$ for that year are significant and positive (0.861).

\subsection{Dividend changes and ROA levels}

In this section we will run the same model as the one from the previous section with the difference being that we will replace ROE for ROA in equations (4) to (6).

The results for the OLS estimation of the dividend change equation support the previous earnings hypothesis since the only significant coefficient is $\alpha_{4}$, presenting values of 0.395 and 0.447 , respectively, for $\mathrm{T}=1$ and $\mathrm{T}=2$.

Regarding the results for the first stage of the 2SLS regressions of the future earnings change equations in its linear and nonlinear forms, the findings are consistent with previous results. The coefficient $\beta=$ is negative and insignificant in both years, a result coincident with Section 4.2, suggesting that dividend changes cannot predict future ROA levels. In terms of control variables only $v_{1}$ is significant and for year $T=2$.

The results for the second stage of the 2SLS regression are consistent with those from its linear counterpart as they show no capacity for dividends to predict future ROA levels since $\alpha_{1}$ is negative and insignificant for both $\mathrm{T}=1$ and $\mathrm{T}=2$. Similarly to its nonlinear model, $v_{1}$ is also positive $(0.072)$ and significant indicating some relation between the market-to-book ratio of equity in year -1 and the ROA of the second year after the event year. After computing the results for this regression we come to the conclusion that there is evidence of the previous earnings hypothesis as the coefficients for $\alpha_{4}$ are positive ( 0.220 and 0.431$)$ and significant in both years and we also find evidence for the free cash flow hypothesis as the coefficient for $\alpha_{2}$ in year $T=1$ is positive (0.869) and significant even if it is not significant for the following year. As for the predictions of the dividend signalling hypothesis the coefficient for $\alpha_{1}$ is negative and significant for $T=1$ but insignificant for the year $\mathrm{T}=2$, which is evidence against the signalling hypothesis.

The results for the nonlinear form are similar to those of its linear counterpart as there is evidence against the dividend signalling hypothesis in year $T=1\left(\alpha_{1}\right.$ is negative and significant) and there is strong evidence of the previous earnings hypothesis in both years ( $\alpha_{4}$ is positive and significant for the two consecutive years). However, contrary to the linear model this regression shows no evidence of the free cash flow hypothesis as $\alpha_{2}$ is insignificant for both years.

\subsection{Dividend changes and future abnormal earnings}

In this section it is performed a final robustness test focused on the relationship between dividend changes and abnormal earnings in each of the two years following the dividend change year. The advantage of abnormal earnings over future earnings is that unlike future earnings, abnormal earnings cannot be affected by other actions such as retained earnings, stock issues and stock repurchases so it allows the test to focus only on the effect of value-creating activities. 
Abnormal future earnings are calculated as total actual earnings after the declining period minus total expected earnings over the same period, whereas expected earnings were those equal to the earnings in the recession period compounded forwards at an historic growth rate for the earnings in the previous years prior to the decline. To obtain the future earnings the only thing left is to standard the results by the shareholder's funds of the period before the initial decline, as expressed in Hussainey and Aal-Eisa (2009):

$$
\frac{\sum \text { Actual earning }(t+1, t+2)-\sum \text { Expected earning }(t+1, t+2)}{\text { Shareholder's funds }(t-1)}
$$

\subsubsection{The model}

The equations for the abnormal future earnings linear model system and abnormal future earnings nonlinear model system, where all the acronyms are the previously defined, are the following:

a Abnormal future earnings linear model system:

Dividend change equation

$$
\begin{aligned}
R \Delta D I V_{0}= & \alpha_{0}+\alpha_{1} A E_{T}+\alpha_{2} P R \triangle F C F D_{-1} \times R \Delta F C F-1 \times N R \Delta Q D_{-1} \times R \Delta Q_{-1} \\
& +\alpha_{3} N R \Delta F C F D_{-1} \times R \Delta F C F-1 \times P R \Delta Q D_{-1} \times R \Delta Q_{-1}+\alpha_{4} R \Delta E_{-1} \\
& +\alpha_{5} N D D i v P_{0} \times R \Delta D i v P_{0}+\alpha_{6} P D D i v P_{0} \times R \Delta D i v P_{0}+\mu_{T}
\end{aligned}
$$

Future earnings change equation

$$
A E_{T}=\beta_{0}+\beta_{1} R \Delta D I V_{0}+\beta_{2} R O E_{T-1}+\beta_{3} C E_{0}+v_{1} M B_{-1}+v_{2} S_{i z e_{-1}}+\varepsilon_{T}
$$

b Abnormal future earnings nonlinear model system:

The dividend change equation is the same as (8) and the future earnings change equation is given by the following equation:

$$
\begin{aligned}
A E_{T}= & \beta_{0}+\beta_{1} R \Delta D I V_{0}+\left(\gamma_{1}+\gamma_{2} N D F D_{0}+\gamma_{3} N D F E D_{0}\right. \\
& \left.\times D F E_{0}+\gamma_{4} P D F E D_{0} \times D F E_{0}\right) \times D F E_{0}+\left(\lambda_{1}+\lambda_{2} N C E D_{0}+\lambda_{3} N C E D_{0}\right. \\
& \left.\times C E_{0}+\lambda_{4} P C E D_{0} \times C E_{0}\right) \times C E_{0}+v_{1} M B_{-1}+v_{2} \text { Size }_{-1}+\varepsilon_{T}
\end{aligned}
$$

\subsubsection{Regression results}

The results for the OLS estimation of the dividend change equation [equation (8)] are similar to the previous models. None of the coefficients are significant with the exception of both $\alpha_{4}$, with their positive sign providing again support to the previous earnings hypothesis, whereas the insignificant coefficient for $\alpha 1$ provides no support for the dividend signalling hypothesis.

Regarding the first stage of the simultaneous equation model, the results of the regression of the future earnings change equation in its linear form [equation (9)] evidence consistency with previous findings as all $\beta_{1}$ are negative and insignificant, meaning that dividend changes cannot be used to predict future earnings. The only difference with previous findings is that $v_{1}$ is not significant in either year which implies 
no relationship between the market-to-book ratio of equity and future abnormal earnings. The results for the first stage of the two stage least square regression in its nonlinear form [equation (10)] provide more support to the idea that dividend changes cannot predict future earnings. This time the coefficient $v_{2}$ is significant in both years, recognising some relationship between total assets in year -1 and abnormal earnings.

The results for the second stage of the 2SLS regression in its linear form [equation (8)] are again similar to the findings from previous sections. The results for $\alpha_{1}$ do not support the dividend signalling theory as $\alpha_{1}$ is negative $(-2.756)$ and extremely significant for year $\mathrm{T}=2$ and positive and insignificant for year $\mathrm{T}=1$. As for the control variables, this time the free cash flow hypothesis is rejected but the previous earnings hypothesis proves extremely resilient once more since $\alpha_{4}$ is positive and significant in both years.

The results for the nonlinear form, unlike its linear counterpart, support the signalling hypothesis theory. However, this time instead of the $\alpha_{1}$ coefficient being significant in year $\mathrm{T}=2$, it is positive (2.339) and significant in year $\mathrm{T}=1$. Unlike its linear counterpart, the coefficient for $\alpha_{2}$ is positive (0.854) and significant in year $T=1$, which also provides support for the free cash flow hypothesis. One hypothesis that seems confirmed after analysing the results of these different models is the previous earnings hypothesis since the coefficient $\alpha_{4}$ is again positive $(0.497$ and 0.381$)$ and extremely significant in both years.

\section{Conclusions}

This paper tests the signalling hypothesis using control variables to assess for other motives that may lead managers to change dividends other than signalling information to investors. The paper builds upon recent models that take into consideration other hypothesis that might explain dividend changes such as the previous earnings changes hypothesis, the free cash flow hypothesis or the dividend clientele hypothesis.

Besides the single-equation OLS basic estimation it was also performed a simultaneous-equation model system using the 2SLS method in order to solve the mutually endogenous problem between dividend changes and future earnings changes. The 2SLS model did indeed prove superior to the OLS-based estimation as it was capable of evidencing the dividend-signalling hypothesis while the OLS estimations only found evidence of the previous earnings changes hypothesis and were absent any signs of dividend-signalling.

After running the models we found that there is some merit to the dividend-signalling hypothesis but the evidence is not absolute like in the study of Liu and Chen (2015) for the North-American market. The difference between the results of our study and the one performed by Liu and Chen (2015) lies in the robustness tests, with those authors finding overwhelming evidence in favour of the signalling hypothesis in those tests while our own robustness tests provided mixed results. On the other hand, our results support that managers change dividends for signalling future equity-scaled earnings changes rather than future asset-scaled earnings changes. As suggested by Liu and Chen (2015), it seems that equity investors are the priority targets of the information managers want to signal. However, contrary to Liu and Chen (2015), it was not found any evidence pointing towards a relation between dividend changes and ROA levels. As for the control variables, we found no evidence that supports the dividend catering hypothesis and some 
evidence towards the free cash flow hypothesis. The previous earnings changes hypothesis however is strongly supported by our model which means that managers do indeed take into consideration the firm's past results and signal the persistence of these firm's earnings. The findings related to the dividend catering hypothesis and the free cash flow hypothesis match those found by Liu and Chen (2015) while the previous earnings changes hypothesis is not fully supported in their study. As for the comparison between the linear and nonlinear formulations of the models we did not find major differences between the results of both formulations. The results mirror the evidence from Liu and Chen (2015) that also found opposite results to those from Grullon et al. (2005).

Our paper analysed data for 16 different European countries, with the 76 considered firms operating in a multinational context, albeit possibly being influenced by dividend policy country-specific factors. This fixed-effects issue is not explicitly considered here but, in the context of an expanded database and time horizon, that is, with a larger and more expressive sample of European countries, it would be interesting to econometrically study the importance of country fixed-effects. Also as a suggestion for future works in the area, it would be interesting to analyse the years surrounding the 2008 financial crisis in order to assess whether it has exerted a significant impact on the firms' dividend policy.

\section{References}

Adam, T. and Goyal, K. (2008) 'The investment opportunity set and its proxy variables', Journal of Financial Research, Vol. 31, No. 1, pp.41-63.

Aharony, J. and Dotan, A. (1994) 'Regular dividend announcements and future unexpected earnings: an empirical analysis', Financial Review, Vol. 29, No. 1, pp.125-151.

Allen, F., Bernardo, A. and Welch, I. (2000) 'A theory of dividends based on tax clienteles', Journal of Finance, Vol. 55, No. 6, pp.2499-2536.

Ap Gwilym, O.A., Seaton, J. and Thomas, S. (2004) Dividend Cuts, Firm Profitability and Financial Characteristics, Discussion Papers in Accounting and Finance, No. AF04-18, p.44.

Baker, H., Mukherjee, K. and Paskelian, G. (2006) 'How Norwegian managers view dividend policy', Global Finance Journal, Vol. 17, No. 1, pp.155-176.

Benartzi, S., Michaely, R. and Thaler, R.H. (1997) 'Do changes in dividends signal the future of the past?', Journal of Finance, Vol. 52, No. 3, pp.1007-1034.

Bhattacharya, S. (1979) 'Imperfect information, dividend policy and the bird in the hand fallacy', Bell Journal of Economics, Vol. 10, No. 1, pp.259-270.

Bozos, K., Nikolopoulos, K. and Ramgandhi, G. (2011) 'Dividend signaling under economic adversity: evidence from the London Stock Exchange', International Review of Financial Analysis, Vol. 20, No. 5, pp.364-374.

Brickley, A. (1983) 'Shareholders wealth, information signalling and the specially designated dividend: an empirical study', Journal of Financial Economics, Vol. 12, No. 2, pp.187-209.

Charitou, A., Lambertides, N. and Theodoulou, G. (2011) 'Dividend increases and initiations and default risk in equity returns', Journal of Financial and Quantitative Analysis, Vol. 46, No. 5, pp.1521-1543.

Damodaran, A. (2006) Damodaran on Valuation, John Wiley and Sons Ltd, New York, NY.

DeAngelo, H. and DeAngelo, L. (1990) 'Dividend policy and financial distress', Journal of Finance, Vol. 45, No. 5, pp.1415-1431.

DeAngelo, H., DeAngelo, L. and Skinner, D.J. (1996) 'Reversal of fortune: dividend policy and the disappearance of sustained earnings growth', Journal of Financial Economics, Vol. 40, No. 3, pp.341-71. 
DeAngelo, H., DeAngelo, L. and Skinner, D.J. (2009) 'Corporate payout policy', Foundations and Trends in Finance, Vol. 3, Nos. 2-3, pp.95-287.

Eades, K.M. (1982) 'Empirical evidence on dividends as a signal of firm value', Journal of Financial and Quantitative Analysis, Vol. 17, No. 4, pp.471-500.

Fama, E.F. and French, K.R. (1998) Dividends, Debt, Investment and Earnings, Working Paper, Graduate School of Business, University of Chicago.

Fama, E.F. and French, K.R. (2000) 'Forecasting profitability and earnings', Journal of Business, Vol. 73, No. 2, pp.161-175.

Fama, E.F. and H. Babiak, (1968) 'Dividend policy: an empirical analysis', Journal of the American Statistical Association, Vol. 63, No. 324, pp.1132-1161.

Ferris, S., Jayraman, N. and Sabherwal, S. (2009) 'Catering effects in corporate dividend policy: the international evidence', Journal of Banking and Finance, Vol. 33, No. 9, pp.1730-1738.

Frankfurter, G.M. and Lane, W.R. (1992) 'The rationality of dividends', International Review of Financial Analysis, Vol. 1, No. 2, pp.115-129.

Fudenberg, D. and Tirole, J. (1995) 'A theory of income and dividend smoothing based in incumbency rents', Journal of Political Economy, Vol. 103, No. 1, pp.75-93.

Grullon, G., Michaely, R. and Swaminathan, B. (2002) 'Are dividend changes a sign of firm maturity?', Journal of Business, Vol. 75, No. 3, pp.387-424.

Grullon, G., Michaely, R., Benartzi, S. and Thaler, R.H. (2005) 'Dividend changes do not signal changes in future profitability', Journal of Business, Vol. 78, No. 5, pp.1659-1682.

Harada, K. and Nguyen, P. (2005) 'Dividend changes context and signalling efficiency in Japan', Pacific-Basin Finance Journal, Vol. 13, No. 5, pp.504-522.

Healy, P. and Palepu, K. (1988) 'Earning information conveyed by dividend initiations and omissions', Journal of Financial Economics, Vol. 21, No. 2, pp.149-175.

Hussainey, K. and Aal-Eisa, J. (2009) 'Disclosure and dividend signalling when sustained earnings growth declines', Managerial Auditing Journal, Vol. 24, No. 5, pp.445-454.

Jensen, M. and Meckling, W. (1976) 'Theory of the firm: managerial behavior, agency costs and ownership structure', Journal of Financial Economics, Vol. 3, No. 4, pp.305-360.

John K. and Williams, J. (1985) 'Dividends, dilution and taxes: a signalling equilibrium', Journal of Finance, Vol. 40, No. 4, pp.1053-1070.

Kao, C. and Wu, C. (1994) 'Tests of dividend signaling using the Marsh-Merton model: a generalized friction approach', Journal of Business, Vol. 67, No. 1, pp.45-68.

Lintner, J. (1956) 'Distribution of incomes of corporations among dividends, retained earnings, and taxes', American Economic Review, Vol. 46, No. 2, pp.97-113.

Litzenberger, R. and Ramaswamy. K (1979) 'The effect of personal taxes and dividends on capital asset prices: theory and empirical evidence', Journal of Financial Economics, Vol. 7, No. 2, pp.163-195.

Liu, C. and Chen, A. (2015) 'Do firms use dividend changes to signal future profitability? A simultaneous equation analysis', International Review of Financial Analysis, Vol. 37, pp.194-207.

Lumby, S. and Jones, C. (1981) Investment Appraisal and Financial Decision, Chapman and Hall, London, reprinted 2000 and 2001.

Marsh, T. and Merton, R. (1987) 'Dividend behavior of the aggregate stock markets', Journal of Business, Vol. 60, No. 1, pp.1-40.

Miller, H. and Rock, K. (1985) 'Dividend policy under asymmetric information', Journal of Finance, Vol. 40, No. 4, pp.1031-1051.

Miller, M. and Modigliani, F. (1961) 'Dividend policy, growth and the valuation of shares', Journal of Business, Vol. 34, No. 4, pp.411-433.

Nissim, D. and Ziv, A. (2001) 'Dividend changes and future profitability', Journal of Finance, Vol. 6, No. 6, pp.2111-2133. 